\title{
PENGARUH PENGGUNAAN APLIKASI TIKTOK TERHADAP PERILAKU KECANDUAN MAHASISWA
}

\author{
Mela Rahmayani, Muhamad Ramdhani, Fardiah Oktariani Lubis \\ Universitas Singaperbangsa Karawang (UNSIKA) Jawa Barat, Indonesia \\ Email:melarahma88@gmail.com,muhamad.ramdhani@staffunsika.ac.id, \\ fardiah.lubis@fisipunsika.ac.id
}

\begin{abstract}
Abstrak
Media sosial merupakan media komunikasi berbasis internet dimana para penggunanya dapat terus berinteraksi tanpa ada batas ruang dan waktu yang menjadi penghambat interaksi manusia pada zaman dulu. Penelitian ini berjudul "Pengaruh Penggunaan Aplikasi TikTok Terhadap Perilaku Kecanduan Mahasiswa (Studi Analisis Regresi Terhadap Penggunaan Aplikasi TikTok Terhadap Perilaku Kecanduan Mahasiswa Ilmu Komunikasi Universitas Singaperbangsa Karawang, Angkatan 2018-2019). Tujuan penelitian ini adalah untuk mengetahui bagaimana pengaruh penggunan aplikasi TikTok terhadap perilaku kecanduan Mahasiswa Universitas Singaperbangsa Karawang, angkatan 2018 dan 2019. Metode penelitian menggunakan metode kuantitatif dan pendekatan analisis regresi linear berganda. Teori yang digunakan adalah teori determinasi teknologi dari McLuhan yang mengasumsikan bahwa setiap teknologi yang diciptakan, maka akan menciptakan pola-pola didalam manusia. Baik pola komunikasi dan perilaku runtunan berpikir, semua pola itu dapat diubah dengan kehadirannya teknologi baru. Hasil yang diperoleh adalah peneliti menemukan bahwa intensitas, dan daya tarik berpengaruh secara signifikan terhadap perilaku kecanduan mahasiswa, sedangkan isi konten pada penggunaan Aplikasi TikTok tidak berpengaruh signifikan terhadap perilaku kecanduan mahasiswa.
\end{abstract}

Kata Kunci: aplikasi TikTok; media sosial; kecanduan

\section{Abstract}

Social media is an internet-based communication media where users can continue to interact without space and time limits which are obstacles to human interaction in the past. This study is entitled "The Effect of the Use of TikTok Applications on Student Addiction Behavior (Study of Regression Analysis of the Use of TikTok Applications on Addiction Behavior of Communication Sciences Students of Singaperbangsa Karawang University, Class of 2018-2019). The purpose of this study was to determine how the effect of using the TikTok application on the addiction behavior of the University of Singapore Karawang Students, class of 2018 and 2019. The research method uses quantitative methods and multiple linear regression analysis approaches. The theory used is McLuhan's Technology Determination Theory, which assumes that every technology created, will create patterns in humans. Good communication patterns, behavioral thinking. All patterns can be changed with 
the presence of new technology. The results obtained are the researchers found that the intensity, and attractiveness significantly influence student addiction behavior, while the content of content on the use of TikTok Application has no significant effect on student addiction behavior.

Keywords: TikTok application; social media; addiction

\section{Pendahuluan}

Saat ini, keberadaan media sosial menjadi suatu kebutuhan bagi manusia. Media sosial dipandang sebagai perantara yang mampu membuat penggunanya mendapat dan menyebarkan informasi secara cepat kepada pengikutnya. Media sosial menjadi salah satu media yang banyak digunakan oleh manusia modern baik untuk berkomunikasi maupun menyebarkan informasi dalam bentuk personal maupun berkelompok. Media sosial dipilih menjadi media komunikasi karena tak lagi perlu adanya batas ruang dan waktu yang dimana menjadi sebuah masalah atau penghalang bagi manusia dalam berkomunikasi di masa lalu (Atikah, 2018).

Era modern, manusia dipermudah melakukan berbagai hal dalam berkomunikasi. Contoh kemudahan yang diciptakan adalah berinteraksi melalui internet. Semakin berkembangnya internet memunculkan pola interaksi yang dapat dilakukan tanpa harus berada dalam ruang dan waktu yang sama. Menurut Anthony Giddens, adanya modernitas hubungan ruang dan waktu terputus kemudian ruang perlahan-lahan terpisah dari tempat (Agustriana, 2019).

Dasar media sosial merupakan perkembangan mutakhir dari teknologi-teknologi perkembangan web baru berbasis internet yang memudahkan semua orang untuk dapat berkomunikasi, berpartisipasi, saling berbagi, dan membentuk sebuah jaringan secara online sehingga dapat menyebarluaskan konten mereka sendiri. Post di blog, tweet, atau video Youtube dapat direproduksi dan dapat dilihat secara langsung oleh jutaan orang secara gratis (Tyas, Budiyanto, \& Santoso, 2015).

Media sosial adalah sebuah media online yang para penggunanya dapat dengan mudah berpartisipasi, berbagi, dan menciptakan isu meliputi blog, jejaring sosial, Wiki, forum, dan dunia virtual. Blog, jejaring sosial, dan Wiki merupakan bentuk yang paling umum digunakan masyarakat diseluruh dunia. (Kaplan \& Haenlein, 2012) mendefinisikan media sosial sebagai sebuah kelompok aplikasi berbasis internet yang dibangun di atas dasar ideologi dan teknologi web yang memungkinkan penciptaan dan pertukaran user generated content (Agustriana, 2019).

Setiap tahunnya para pencipta teknologi berusaha melahirkan inovasi-inovasi terbaru dengan memasukan fitur-fitur menarik ke dalam media sosial yang dapat bersaing dan menjadi media sosial unggulan dari pada media sosial lainnya. Sebut saja seperti Facebook, Twitter, Instagram, Youtube, dan masih banyak lagi media sosial yang menawarkan kecanggihan-kecanggihan fitur dari setiap aplikasi mereka demi menarik para peminat media sosial. Tidak hanya digunakan sebagai media berkomunikasi dan menyebarkan informasi, beberapa media sosial sengaja diciptakan sebagai media yang dapat menghibur penggunanya. Saat ini banyak sekali aplikasi media sosial yang 
diciptakan dengan tujuan menghibur, baik aplikasi berbasis game, audio, visual maupun audio visual. Contohnya adalah aplikasi TikTok yang cukup populer di Indonesia (Hayati, 2020).

Berdasarkan hasil riset Wearesocial Hootsuite yang dirilis Januari 2019 pengguna media sosial di Indonesia mencapai 150 juta atau sebesar $56 \%$ dari total populasi. Jumlah tersebut naik $20 \%$ dari survei sebelumnya. Sementara pengguna media sosial mobile (gadget) mencapai 130 juta atau sekitar 48\% dari populasi (Damar, 2019). Pengguna internet jika dilihat berdasarkan jenis kelamin maka sebanyak $48,57 \%$ pengguna internet adalah wanita dan $51,43 \%$ pengguna internet adalah laki-laki. Jika dilihat dari komposisi pengguna internet berdasarkan usia, sebanyak 49,52\% pengguna internet masih tergolong kedalam masa dewasa muda yang berusia sekitar $18-25$ tahun (Santrock, 2011). Menurut (Santrock, 2011) rentang usia masa dewasa muda adalah 18-25 tahun sedangkan menurut (Hurlock \& Oldfield, 2015) usia dewasa muda adalah 18-40 tahun. Dewasa muda atau dewasa awal adalah masanya bekerja dan jatuh cinta, terkadang hanya menyisakan waktu sedikit untuk hal-hal lain (Mawardah, 2019).

Terhitung pada bulan November 2019, Aplikasi TikTok menjadi aplikasi non-game yang banyak diunduh. Sebanyak 1,5 Miliar pengguna TikTok dari seluruh dunia, mengalahkan aplikasi Instagram yang diunduh sebanyak 1 Milyar. Jumlah pengguna TikTok meningkat pesat dari 10 juta unduhan dari tahun sebelumnya (CNN, 2019). Pada Januari 2020, jumlah unduhan Aplikasi TikTok mengalahkan Facebook dan Instagram. Menurut data dari Sensor Tower, TikTok berada diperingkat kedua dengan jumlah unduhan lebih dari 700 juta pengguna didunia pada 2019 sedangkan Facebook diposisi keempat dan Instagram diurutan kelima. Sensor Tower menghitung data ini dari Google Play Store di Android dan App Store di IOS (Ferdiansyah, 2020).

Berdasarkan penelitian ini, peneliti menggunakan teori determinasi teknologi yang diperkenalkan oleh McLuhan. McLuhan dalam (Surahman, 2016) mengenalkan teori determinasi pada tahun 1962 dalam tulisannya yang berjudul "The Guttenberg Galaxy: The Making of Typographic Man”. Pokok gagasan teori ini adalah bahwa perubahan yang terjadi dalam berbagai macam cara berkomunikasi akan membentuk pola keberadaan manusia itu sendiri. Teknologi membentuk individu bagaimana cara berpikir dan berperilaku dalam masyarakat dan teknologi tersebut akhirnya mengarahkan manusia untuk bergerak dari satu abad teknologi ke abad teknologi yang lain. Teori determinasi teknologi yang dikembangkan oleh McLuhan mengungkapkan bagaimana sebuah teknologi baru khususnya teknologi komunikasi yang dibuat dapat menciptakan pola-pola baru yang ada didalam manusia baik itu pola komunikasi, perilaku, dan runtunan berpikir. Semua pola itu dapat berubah atau menghasilkan pola baru yang diciptakan oleh keberadaan teknologi (Tristan, Sadono, \& Marta, 2019).

Berdasarkan penjelasan diatas, peneliti tertarik untuk melakukan penelitian dengan judul "Pengaruh Penggunaan Aplikasi TikTok terhadap Perilaku Kecanduan Mahasiswa Ilmu Komunikasi Universitas Singaperbangsa Karawang Angkatan 2018 dan angkatan 2019”, penelitian ini pun dibuat untuk mengetahui seberapa pengaruh penggunaan 
aplikasi TikTok terhadap perilaku kecanduan pada ilmu komunikasi di Universitas Singaperbangsa Karawang.

Peneliti memutuskan untuk menggunakan penelitian terdahulu sebagai referensi dan perbandingan, penelitian yang digunakan penulis sebagai bahan referensi dan bahan perbandingan adalah penelitian yang dilakukan oleh (Prianbodo, 2018), Jurusan Ilmu Komunikasi, Sekolah Tinggi Ilmu Komunikasi, almamater Wartawan Surabaya tentang "Pengaruh TikTok terhadap Kreativitas Remaja Surabaya". Metode yang digunakan adalah metode penelitian kuantitatif dengan menggunakan Skala Likert. Penelitian ini bertujuan untuk mengetahui seberapa besar pengaruh Tik Tok terhadap kreativitas remaja Surabaya. Hasil dari penelitian ini adalah mayoritas responden yaitu 39 responden (39\%) menggunakan aplikasi “TikTok" sampai 6-10 kali sehari. Menunjukkan bahwa mayoritas responden berada kategori "Lama" dalam menggunakan aplikasi "TikTok". Sedangkan 46 responden $46 \%$ menggunakan aplikasi tersebut selama 30 menit. Menunjukkan bahwa mayoritas responden berada dikategori "Cukup Lama" dalam menggunakan aplikasi tersebut. Pada tabel atensi, mayoritas responden yang menyatakan menarik terhadap aplikasi "TikTok", sebanyak 55 responden atau 55\% ketertarikan mereka terhadap aplikasi tersebut. Berdasarkan penelitian ini, peneliti menyimpulkan bahwa aplikasi "TikTok" memiliki pengaruh sebesar $41,6 \%$ terhadap tingkat kreativitas remaja Surabaya, penggunaan Aplikasi TikTok dapat berpengaruh terhadap tingkat kreativitas remaja Surabaya. Persamaan dalam penelitian terdahulu dan penelitian ini yang pertama adalah pada variabel bebas (x) penelitian. Kedua, penelitian sama-sama menggunakan Aplikasi TikTok sebagai variabel bebas (x). Ketiga, penelitian menggunakan metode penelitian kuantitatif. Perbedaan penelitian terdahulu dan penelitian ini yang pertama adalah pada variabel terikat (y) yang digunakan berbeda, pada penelitian terdahulu variabel terikat (y) adalah untuk mengetahui kreativitas remaja Surabaya sedangkan pada penelitian ini variabel terikat (y) yang digunakan adalah mencari tahu pengaruh kecanduan dalam penggunaan Aplikasi Tiktok. Kedua, objek dan tempat yang dilakukan berbeda, pada penelitian pertama dilakukan pada remaja Surabaya sedangkan pada penelitian ini dilakukan pada Mahasiswa Univeristas Singaperbangsa Karawang, Angkatan 2018-2019.

Tujuan penelitian adalah untuk mengetahui bagaimana pengaruh antara intensitas Aplikasi TikTok terhadap perilaku kecanduan pada mahasiswa Ilmu Komunikasi angkatan 2018-2019 Universitas Singaperbangsa Karawang. Untuk mengetahui bagaimana pengaruh antara isi konten Aplikasi TikTok terhadap perilaku kecanduan pada mahasiswa Ilmu Komunikasi angkatan 2018-2019 Universitas Singaperbangsa Karawang. Untuk mengetahui bagaimana pengaruh antara daya tarik penggunaan Aplikasi TikTok terhadap perilaku kecanduan pada mahasiswa Ilmu Komunikasi angkatan 2018-2019 Universitas Singaperbangsa Karawang.

\section{Metode Penelitian}

Metode penelitian yang digunakan adalah dengan pendekatan kuantitatif dan lebih banyak menggunakan metode pengumpulan data, seperti angket, wawancara, angket, 
focus group discussion, analisis isi kuantitatif, dokumentasi, teknik visualisasi, dan sebagainya tergantung pada objek penelitian mana yang sedang diteliti.

Menurut (Sugiyono, 2017) terdapat dua hal utama yang memengaruhi kualitas data hasil penelitian, yaitu kualitas instrumen penelitian dan kualitas pengumpulan data. Pengumpulan data dapat dilakukan dalam berbagai setting, berbagai sumber dan berbagai cara. Bila dilihat dari berbagai cara atau teknik pengumpulan data, maka teknik pengumpulan data dapat dilakukan dengan interview (wawancara), kuesioner (angket), observasi (pengamatan), dan gabungan ketiganya (Bungin, 2009). Adapun teknik pengumpulan data yang dilakukan penulis dalam penelitian ini adalah:

1. Angket atau kuesioner

Kuesioner merupakan teknik pengumpulan data yang dilakukan dengan cara memberi seperangkat pertanyaan lisan atau tertulis pada responden untuk dijawabnya (Sugiyono, 2017). Responden dalam penelitian adalah Mahasiswa Ilmu Komunikasi Universitas Singaperbangsa Karawang angkatan 2018-2019 yang memiliki aplikasi TikTok.

2. Kepustakaan

Mengumpulkan data dan informasi yang diperlukan melalui buku-buku dan sumber-sumber tertulis lainnya yang relevan dengan obyek yang diteliti.

Berdasarkan penelitian ini, peneliti menggunakan teknik Nonprobality Sampling yang dikemukakan oleh (Sugiyono, 2017). Nonprobality Sampling adalah teknik pengambilan sampel yang tidak memberi peluang atau kesempatan sama bagi setiap unsur (anggota) populasi untuk dipilih menjadi sampel. Teknik pengambilan sampel pada penelitian ini, peneliti menggunakan sensus atau sampling total. Sampling total adalah teknik pengambilan sampel di mana seluruh anggota populasi dijadikan sampel.

\section{Hasil dan Pembahasan}

\section{A. Hasil Penelitian}

1. Identifikasi Responden

Penelitian ini telah disebarkan kuesioner kepada mahasiswa dan mahasiswi Prodi Ilmu Komunikasi Universitas Singaperbangsa Karawang. Identifikasi responden yang akan disajikan berikut ini digambarkan berdasarkan jenis kelamin dan angkatan untuk mengetahui bagaimana keadaan responden yang akan diteliti di Prodi Ilmu Komunikasi Universitas Singaperbangsa Karawang angkatan 20182019.

Tabel 1

Identifikasi Responden berdasarkan Jenis Kelamin

\begin{tabular}{ccc}
\hline Jenis_Kelamin & Frequency & Percent \\
\hline Perempuan & 53 & 81,5 \\
\hline Laki-Laki & 12 & 18,5 \\
\hline Total & $\mathbf{6 5}$ & $\mathbf{1 0 0 , 0}$ \\
\hline
\end{tabular}

Sumber: Data diolah peneliti 
Berdasarkan tabel 1 diketahui dari seluruh jumlah responden yang mengakses dan menggunakan aplikasi TikTok, responden perempuan lebih banyak dari pada laki-laki yaitu sebanyak 53 Mahasiswi $(81,5 \%)$ dan responden mahasiswa sebanyak $12(18,5 \%)$.

\section{Tabel 2}

Identifikasi Responden Berdasarkan Angkatan

\begin{tabular}{lll}
\hline Angkatan & Frequency & Percent \\
\hline 2019 & 32 & 49,2 \\
\hline 2018 & 33 & 50,8 \\
\hline Total & $\mathbf{6 5}$ & $\mathbf{1 0 0 , 0}$ \\
\hline
\end{tabular}

Sumber: Data diolah peneliti

Berdasarkan tabel 2 diketahui bahwa seluruh responden yang terbanyak mengisi kuesioner terdapat pada angkatan 2018 dengan 32 responden $(50,8 \%)$ dan angkatan 2019 dengan 32 responden (49,2\%).

2. Analisis Sub Variabel Intensitas (X1)

Analisis deskripsi variabel penelitian dilakukan untuk mengetahui sebaran nilai dari variabel-variabel penelitian. Hal-hal yang akan dikaji dalam membahas deskripsi variabel penelitian adalah banyaknya responden pada tiap-tiap kategori penilaian. Berikut hasil analisis dari sub variabel intensitas yang memuat delapan variasi pertanyaan:

Tabel 3

Tanggapan Responden Pernyataan Tanggapan Responden Pernyataan

\begin{tabular}{clcc}
\hline Pertanyaan & Jawaban Responden & Frequency & Percent \\
\hline Saya sering & SANGAT SETUJU & 12 & 18,5 \\
\cline { 2 - 4 } $\begin{array}{c}\text { membuka } \\
\text { aplikasi }\end{array}$ & SETUJU & 18 & 27,7 \\
\cline { 2 - 4 } $\begin{array}{c}\text { TikTok pada } \\
\text { ponsel saya }\end{array}$ & KURANG SETUJU & 23 & 35,4 \\
\cline { 2 - 4 } & $\begin{array}{l}\text { SIDAK SETUJU } \\
\text { SANGAT TIDAK }\end{array}$ & 5 & 7,7 \\
\cline { 2 - 4 } & SETUJU & 7 & 10,8 \\
\hline
\end{tabular}

Sumber: Data diolah peneliti

Data tabel 3 menunjukkan bahwa jumlah responden yang menjawab sangat setuju terhadap pernyataan tentang saya sering membuka aplikasi TikTok pada ponsel saya adalah sebanyak 12 orang $(18,5 \%)$, jumlah responden yang menjawab setuju terhadap pernyataan tentang Saya Sering membuka aplikasi TikTok pada ponsel saya adalah sebanyak 18 orang $(27,7 \%)$, jumlah responden yang menjawab kurang setuju terhadap pernyataan tentang saya sering membuka aplikasi TikTok pada ponsel saya adalah sebanyak 23 orang $(35,4 \%)$, sedangkan yang menjawab tidak setuju dan sangat tidak setuju berjumlah 5 dan 7 orang dengan persentase $7,7 \%$ dan $10,8 \%$. 
3. Analisis Sub Variabel Isi Konten (X2)

Analisis deskripsi variabel penelitian dilakukan untuk mengetahui sebaran nilai dari variabel-variabel penelitian. Hal-hal yang akan dikaji dalam membahas deskripsi variabel penelitian adalah banyaknya responden pada tiap-tiap kategori penilaian. Berikut hasil analisis dari sub variabel isi konten yang memuat sepuluh variasi pertanyaan:

\section{Tabel 4}

Tanggapan Responden Pernyataan Video dalam Aplikasi TikTok Memberikan Informasi Bagi Pengguna

\begin{tabular}{clcc}
\hline Pertanyaan & Jawaban Responden & Frequency & Percent \\
\hline Video dalam aplikasi & SANGAT SETUJU & 12 & 18,5 \\
\cline { 2 - 4 } TikTok memberikan & SETUJU & 24 & 36,9 \\
\cline { 2 - 4 } informasi bagi pengguna & KURANG SETUJU & 20 & 30,8 \\
\cline { 2 - 4 } & TIDAK SETUJU & 5 & 7,7 \\
\cline { 2 - 4 } & $\begin{array}{llc}\text { SANGAT TIDAK } \\
\text { SETUJU }\end{array}$ & 4 & 6,2 \\
\cline { 2 - 4 } & \multicolumn{1}{c}{ Total } & $\mathbf{6 5}$ & $\mathbf{1 0 0 , 0}$ \\
\hline
\end{tabular}

Sumber: Data diolah peneliti

Data tabel 4 menunjukkan bahwa jumlah responden yang menjawab sangat setuju terhadap pernyataan tentang video dalam aplikasi TikTok memberikan informasi bagi pengguna adalah sebanyak 12 orang (18,5\%), jumlah responden yang menjawab setuju terhadap pernyataan video dalam aplikasi TikTok memberikan informasi bagi pengguna adalah sebanyak 24 orang $(36,9 \%)$, jumlah responden yang menjawab kurang setuju terhadap pernyataan tentang video dalam aplikasi TikTok memberikan informasi bagi pengguna adalah sebanyak 20 orang (30,8\%), sedangkan yang menjawab tidak setuju dan sangat tidak setuju berjumlah 5 dan 4 orang dengan persentase $7,7 \%$ dan $6,2 \%$.

4. Analisis Sub Variabel Daya Tarik (X3)

Analisis deskripsi variabel penelitian dilakukan untuk mengetahui sebaran nilai dari variabel-variabel penelitian. Hal-hal yang akan dikaji dalam membahas deskripsi variabel penelitian adalah banyaknya responden pada tiap-tiap kategori penilaian. Berikut hasil analisis dari sub variabel daya tarik yang memuat tujuh variasi pertanyaan.

Tabel 5

Tanggapan Responden Pernyataan Musik di dalam Aplikasi TikTok Sangat Menarik

\begin{tabular}{cllc}
\hline Pertanyaan & Jawaban Responden & Frequency & Percent \\
\hline Musik didalam & SANGAT SETUJU & 24 & 36,9 \\
\cline { 2 - 4 } aplikasi TikTok & SETUJU & 27 & 41,5 \\
\cline { 2 - 4 } sangat menarik & KURANG SETUJU & 12 & 18,5 \\
\cline { 2 - 4 } & TIDAK SETUJU & 2 & 3,1 \\
\cline { 2 - 4 } & \multicolumn{1}{c}{ Total } & $\mathbf{6 5}$ & $\mathbf{1 0 0 , 0}$ \\
\hline
\end{tabular}

Sumber: Data diolah peneliti 
Data diatas menunjukkan bahwa jumlah responden yang menjawab sangat setuju terhadap pernyataan tentang Musik didalam aplikasi TikTok sangat menarik adalah sebanyak 24 orang (36,9\%), jumlah responden yang menjawab setuju terhadap Musik didalam aplikasi TikTok sangat menarik adalah sebanyak 27 orang (41,5\%), jumlah responden yang menjawab kurang setuju Musik didalam aplikasi TikTok sangat menarik adalah sebanyak 12 orang (18,5\%), sedangkan yang menjawab tidak setuju berjumlah 2 orang dengan persentase $3,1 \%$.

5. Analisis Variabel Perilaku Kecanduan Mahasiswa (Y)

Analisis deskripsi variabel penelitian dilakukan untuk mengetahui sebaran nilai dari variabel-variabel penelitian. Hal-hal yang akan dikaji dalam membahas deskripsi variabel penelitian adalah banyaknya responden pada tiap-tiap kategori penilaian. Berikut hasil analisis dari variabel perilaku kecanduan mahasiswa yang memuat sepuluh variasi pertanyaan:

\section{Tabel 6}

Tanggapan Responden Pernyataan setelah Mengakses Aplikasi TikTok Pengguna Merasa Ingin Terus Mengakses dan Melihat-Lihat Video didalam Aplikasi TikTok

\begin{tabular}{|c|c|c|c|}
\hline Pertanyaan & Jawaban Responden & Frequency & Percent \\
\hline \multirow{6}{*}{$\begin{array}{l}\text { Setelah mengakses } \\
\text { aplikasi } \\
\text { pengguna merasa ingin } \\
\text { terus mengakses dan } \\
\text { melihat-lihat video } \\
\text { didalam aplikasi TikTok }\end{array}$} & SANGAT SETUJU & 15 & 23,1 \\
\hline & SETUJU & 18 & 27,7 \\
\hline & KURANG SETUJU & 18 & 27,7 \\
\hline & TIDAK SETUJU & 7 & 10,8 \\
\hline & SANGAT TIDAK & 7 & 10,8 \\
\hline & SETUJU & & \\
\hline
\end{tabular}

Sumber: Data diolah peneliti

Data Tabel 6 menunjukkan bahwa jumlah responden yang menjawab sangat setuju terhadap pernyataan tentang setelah mengakses aplikasi TikTok pengguna merasa ingin terus mengakses dan melihat-lihat video didalam aplikasi TikTok adalah sebanyak 15 orang $(23,1 \%)$, jumlah responden yang menjawab setuju terhadap Setelah mengakses aplikasi TikTok pengguna merasa ingin terus mengakses dan melihat-lihat video didalam aplikasi TikTok adalah sebanyak 18 orang $(27,7 \%)$, jumlah responden yang menjawab kurang setuju Setelah mengakses aplikasi TikTok pengguna merasa ingin terus mengakses dan melihat-lihat video didalam aplikasi TikTok adalah sebanyak 18 orang (27,7\%), sedangkan yang menjawab tidak setuju dan sangat tidak setuju berjumlah 7 dan 7 orang dengan persentase $10,8 \%$ dan $10,8 \%$.

6. Uji Asumsi Klasik

a. Uji Normalitas

Menurut Singgih Susanto dalam (Janie, 2012) mengatakan bahwa uji normalitas data menggunakan statistik SPSS Kolmograv Smirnov dengan dasar pengambilan keputusan bisa dilakukan probabilitas (asymptotic significancy) lebih besar dari 0,05 maka data terdistribusi normal. 
Tabel 7

Uji Normalitas

\begin{tabular}{llr}
\hline & & $\begin{array}{c}\text { Unstandardized } \\
\text { Residual }\end{array}$ \\
\hline $\mathrm{N}$ & Mean & 65 \\
\hline Normal Parameters ${ }^{\mathrm{a}, \mathrm{b}}$ & Std. Deviation & 0,0000000 \\
\hline Most Extreme Differences & Absolute & 5,42204384 \\
\hline & Positive & 0,078 \\
\hline & Negative & 0,078 \\
\hline Test Statistic & & $-0,070$ \\
\hline Asymp. Sig. (2-tailed) & & 0,078 \\
\hline
\end{tabular}

Sumber: Data diolah peneliti

Berdasarkan tabe1 7, hasil Output SPSS 22 dapat dilihat bahwa hasil uji normalitas menyatakan nilai Asymp. Sig. (2-tailed) sebesar $0.797>0,05$. Berdasarkan hasil tersebut dapat dinyatakan data yang digunakan dalam penelitian ini telah berdistribusi normal.

b. Uji Multikoliniaritas

Model regresi yang baik seharusnya tidak terjadi korelasi antar variabel independen (Ghozali, 2017). Multikoliniaritas dapat dilihat dari nilai Tolerance dan nilai Variance Inflation Factor (VIF). Jika nilai Tolerance $>0,1$ atau sama dengan nilai 91 VIF < 10, maka dapat disimpulkan bahwa tidak ada multikoliniaritas antar variabel independen dalam model regresi pada penelitian ini.

\section{Tabel 8}

Uji Multikoliniaritas

\begin{tabular}{|c|c|c|c|}
\hline \multirow[t]{2}{*}{ Model } & & \multicolumn{2}{|c|}{ Collinearity Statistics } \\
\hline & & Tolerance & VIF \\
\hline 1 & (Constant) & & \\
\hline & $\mathrm{X} 1$ Intensitas & 0,633 & 1,579 \\
\hline & X2 Isi konten & 0,442 & 2,265 \\
\hline & X3 Daya Tarik & 0,428 & 2,335 \\
\hline
\end{tabular}

Sumber: Data diolah peneliti

Berdasarkan Tabel 8, hasil Output SPSS 22 dapat dilihat bahwa intensitas (X1) nilai VIF 1,579 < 10, Isi konten (X2) nilai VIF 2,265 < 10, dan daya tarik (X3) nilai VIF 2,335 < 10. Jadi dapat disimpulkan bahwa tidak ada gejala multikolinearitas antar variabel independen.

c. Uji Heteroskedastisitas

Heterostisiditas merupakan indikasi pada varian antar residual tidak homogen digunakan uji Rank Spearman. Apabila ada koefisien korelasi yang signifikan pada tingkat kekeliruan 5\% mengindikasikan adanya heteroskedastisitas. 


\section{Tabel 9}

Uji Heteroskedastisitas

\begin{tabular}{clccccc}
\hline ABS_RES & X1 & X2 & X3 & Y & \\
& $\begin{array}{l}\text { Correlation } \\
\text { Coefficient }\end{array}$ & $-0,043$ & 0,052 & 0,066 & $-0,035$ & 1,000 \\
\hline $\begin{array}{l}\text { Sig. (2- } \\
\text { tailed) }\end{array}$ & 0,736 & 0,681 & 0,602 & 0,780 & \\
\hline $\mathrm{N}$ & 65 & 65 & 65 & 65 & 65 \\
\hline
\end{tabular}

Sumber: Data diolah peneliti

Berdasarkan Tabel 9, hasil Output SPSS 22 dapat dilihat bahwa intensitas (X1) Sig. (2-tailed) 0,736>0,05, isi konten (X2) Sig. (2-tailed) 0,681 >0,05, daya tarik (X3)Sig. (2-tailed) 0,602 > 0,05, dan perilaku kecanduan Y Sig. (2-tailed) $0,780>0,05$. Jadi dapat disimpulkan bahwa tidak ada gejala Heteroskedastisitas.

3. Analisis Regresi Linier Berganda

a. Persamaan Regresi

Analisis regresi linier berganda digunakan untuk mengetahui seberapa besar pengaruh hubungan variabel intensitas (X1), isi konten (X2), dan daya tarik (X3), terhadap variabel dependen perilaku kecanduan (Y).

Tabel 10

Analisis Linier Berganda

\begin{tabular}{|c|c|c|c|c|}
\hline \multirow{2}{*}{\multicolumn{2}{|c|}{ Model }} & \multicolumn{2}{|c|}{$\begin{array}{c}\text { Unstandardized } \\
\text { Coefficients }\end{array}$} & \multirow{2}{*}{$\begin{array}{c}\begin{array}{c}\text { Standardized } \\
\text { Coefficients }\end{array} \\
\text { Beta }\end{array}$} \\
\hline & & B & Std. Error & \\
\hline \multirow[t]{4}{*}{1} & (Constant) & 2,563 & 4,044 & \\
\hline & $\mathrm{X} 1$ & ,471 &, 102 & 476 \\
\hline & $\mathrm{X} 2$ &,- 127 & ,142 &,- 111 \\
\hline & $\mathrm{X} 3$ & ,748 & ,198 & , 474 \\
\hline
\end{tabular}

Berdasarkan tabel 10 hasil Output SPSS 22, maka didapatkan tabel regresi linier berganda sebagai berikut:

$$
Y=2,563+0,471 X 1-0,127 X 2+0,748 X 3
$$

Persamaan diatas dapat dijelaskan sebagai berikut:

a. Koefisien $\mathrm{X} 1=0,471$

Sub variabel intensitas $\mathrm{X} 1$ adalah bernilai positif, sehingga dapat dikatakan bahwa semakin tinggi Intensitas penggunaan aplikasi maka semakin tinggi pula perilaku kecanduan.

b. Koefisien X2=-0,127

Sub variabel isi konten $\mathrm{X} 2$ adalah bernilai negatif, sehingga dapat dikatakan bahwa semakin tinggi isi konten maka semakin berkurang pula perilaku kecanduan. 
c. Koefisien $\mathrm{X} 3=0,748$

Sub variabel daya tarik X3 adalah bernilai positif, sehingga dapat dikatakan bahwa semakin tinggi daya tarik maka semakin tinggi pula perilaku kecanduan.

b. Uji F (Simultan)

Uji statistik $F$ pada dasarnya menunjukkan apakah semua variabel independen atau bebas yang dimasukkan dalam model mempunyai pengaruh secara bersama-sama terhadap variabel dependen (terikat). Hipotesis nol (H0) yang hendak diuji adalah apakah semua parameter dalam model sama dengan nol (Ghozali, 2013)). Dari hasil Uji F software SPSS, maka didapatkan uji f seperti yang terdapat pada tabel berikut:

Tabel 11

Uji F (simultan)

\begin{tabular}{lccc}
\hline Model & F & Sig. \\
\hline $\mathbf{1}$ & Regression & 28,880 & $.000^{\mathrm{b}}$ \\
\hline \multicolumn{3}{c}{ Sumber: Data diolah peneliti }
\end{tabular}

Berdasarkan tabel 11, hasil Output SPSS 22 diatas diketahui nilai signifikan untuk pengaruh intensitas (X1), isi konten (X2), daya tarik (X3) secara simultan terhadap perilaku kecanduan (Y) adalah F hitung 28,880 > 2,75 F tabel, sehingga dapat disimpulkan bahwa Ha diterima, berarti terdapat pengaruh intensitas (X1), isi konten (X2), daya tarik (X3) secara simultan terhadap perilaku kecanduan (Y).

c. Uji T (Parsial)

Tabel 12

Uji T (Parsial)

\begin{tabular}{llrr}
\hline \multicolumn{1}{l}{ Model } & \multicolumn{1}{c}{ T } & \multicolumn{1}{c}{ Sig. } \\
& & & \\
\hline 1 & (Constant) &, 634 &, 529 \\
\cline { 2 - 4 } & X1 & 4,603 &, 000 \\
\cline { 2 - 4 } & X2 &,- 894 &, 375 \\
\hline & X3 & 3,770 &, 000 \\
\hline
\end{tabular}

Sumber: Data diolah peneliti

a. Variabel Intensitas ( X1)

1) Ho : b1 < 0 : Intensitas tidak berpengaruh signifikan terhadap perilaku kecanduan.

2) Ha : b1 > 0 : Intensitas berpengaruh signifikan terhadap perilaku kecanduan.

Hasil pengujian dengan tabel hasil Output SPSS 22 diperoleh untuk variabel X1 (intensitas) diperoleh nilai t hitung $=4,60$ dengan tingkat $\mathrm{T}$ tabel 4,60 > 1,99 yang berarti Ha diterima dan H0 ditolak. Dengan demikian, hipotesis pertama diterima yang berarti intensitas berpengaruh signifikan terhadap perilaku kecanduan. 
b. Variabel Isi konten (X2)

1. Ho : b1 < 0 : Isi konten tidak berpengaruh signifikan terhadap perilaku kecanduan

2. Ha : b1 >0 : Isi konten berpengaruh signifikan terhadap perilaku kecanduan

Hasil pengujian dengan tabel hasil Output SPSS 22 diperoleh untuk variabel X2 (isi konten) diperoleh nilai t hitung $=-0,89$ dengan tingkat Ttabel $0,89<1,99$ yang berarti Ha ditolak dan $\mathrm{H} 0$ diterima. Dengan demikian, hipotesis pertama ditolak yang berarti isi konten tidak berpengaruh signifikan terhadap perilaku kecanduan.

c. Variabel Daya tarik (X3)

1. Ho : b1 < 0 : Daya tarik tidak berpengaruh signifikan terhadap Perilaku kecanduan

2. Ha : b1 > 0 : Daya tarik berpengaruh signifikan terhadap Perilaku kecanduan

Hasil pengujian dengan tabel hasil Output SPSS 22 diperoleh untuk variabel X3 (daya tarik) diperoleh nilai $\mathrm{t}$ hitung $=3,77$ dengan tingkat Ttabel 3,77> 1,99 yang berarti Ha diterima dan H0 ditolak. Dengan demikian, hipotesis pertama diterima yang berarti daya tarik berpengaruh signifikan terhadap perilaku kecanduan.

d. Koefisien Determinasi Ganda (R2)

Nilai yang dilakukan pada penelitian ini adalah menggunakan nilai R2 (Adjusted $\mathrm{R}$ Square), dikarenakan nilai tersebut dapat naik dan turun apabila satu variabel bebas ditambahkan kedalam model yang diuji dan dapat dilihat model nya seperti berikut:

\section{Tabel 13}

Koefisien Determinasi Ganda

\begin{tabular}{ccccc}
\hline Model & $\mathbf{R}$ & $\begin{array}{c}\mathbf{R} \\
\text { Square }\end{array}$ & $\begin{array}{c}\text { Adjusted } \\
\mathbf{R} \\
\text { Square }\end{array}$ & $\begin{array}{c}\text { Std. Error } \\
\text { of the } \\
\text { Estimate }\end{array}$ \\
\hline 1 & $.766^{\mathrm{a}}$ & 0,587 & 0,567 & 5,554 \\
\hline \multicolumn{4}{c}{ Sumber: Data diolah peneliti } \\
\end{tabular}

Tabel hasil Output SPSS 22 diatas dapat dijelaskan bahwa nilai R2 Adjusted $\mathrm{R}$ Square sebesar 0,567. Hal ini dapat diartikan bahwa variabel independen (intensitas, isi konten, dan daya tarik) dapat menjelaskan variabel dependen (perilaku kecanduan) sebesar 56,7\%, sedangkan sisa persentase nya adalah diterangkan oleh faktor lain yang tidak diteliti. 
a. Koefisien Determinasi Parsial (r2)

Tabel 14

Koefisien Determinasi Parsial

\begin{tabular}{llrrr}
\hline \multirow{2}{*}{ Model } & \multicolumn{3}{c}{ Correlations } \\
\cline { 3 - 5 } & & Zero-order & Partial & $r^{2}$ \\
\hline 1 & (Constant) & & & \\
\cline { 2 - 5 } X1 &, 686 &, 508 &, 258 \\
\hline &, 498 &,- 114 &, 013 \\
\hline X2 &, 666 &, 435 &, 189 \\
\hline
\end{tabular}

Sumber: Data diolah peneliti

Berdasarkan tabel 14 hasil Output SPSS 22 diatas, diketahui besarnya pengaruh intensitas terhadap tingkat perilaku kecanduan adalah 0,5082 $=25,8 \%$. Besarnya pengaruh isi konten terhadap tingkat perilaku kecanduan adalah $0,1142=1,3 \%$. Besarnya daya tarik terhadap tingkat perilaku kecanduan adalah $0,4352=18,9 \%$.

B. Pembahasan

Setelah menyebarkan kuesioner kepada 65 responden, lalu mengkaji dan menganalisis data yang didapat. Peneliti mendapatkan hasil bahwa penggunaan aplikasi TikTok berpengaruh terhadap perilaku kecanduan pada mahasiswa ilmu komunikasi Universitas Singaperbangsa Karawang tahun angkatan 2018-2019. Dari uji regresi linear berganda didapat persamaan sebagai berikut:

$$
\mathrm{Y}=2,653+0,471 \mathrm{X} 1+-0,127 \mathrm{X} 2+0,748 \mathrm{X} 3
$$

Persamaan tersebut dapat diperoleh pernyataan bahwa ketiga variabel yang merupakan variabel independent atau bebas dalam penelitian ini adalah bernilai positif terhadap perilaku kecanduan. Hal tersebut juga menunjukkan bahwa secara bersamaan intensitas, isi pesan, dan daya tarik penggunaan aplikasi TikTok berpengaruh signifikan terhadap perilaku kecanduan mahasiswa Ilmu Komunikasi UNIVERSITAS SINGAPERBANGSA KARAWANG. Besarnya pengaruh ketiga variabel terhadap perilaku kecanduan adalah 56,7\%, sehingga dapat disimpulkan bahwa Ha diterima yang berarti terdapat pengaruh intensitas (X1), isi Konten (X2), daya tarik (X3) secara simultan terhadap perilaku kacanduan (Y). Fakta tersebut menunjukkan variabelvariabel tersebut merupakan aspek yang sangat dominan dalam memengaruhi penggunaan aplikasi terhadap perilaku kecanduan mahasiswa.

Hasil penelitian menunjukkan intensitas penggunaan aplikasti TikTok secara signifikan terhadap perilaku kecanduan mahasiswa. Besarnya pengaruh intensitas penggunaan aplikasi TikTok terhadap perilaku kencaduan adalah $25,8 \%$. Nilai tersebut menunjukkan bahwa responden cukup aktif dalam mengakses aplikasi TikTok.

Hasil penelitian menunjukkan isi konten berpengaruh secara negatif atau tidak berpengaruh terhadap perilaku kecanduan mahasiswa. Besarnya pengaruh isi konten 
terhadap perilaku kecanduan mahasiswa adalah 1,3\%, hal tersebut menunjukkan seberapa banyak isi konten didalam aplikasi TikTok tidak berpengaruh signifikan terhadap perilaku kecanduan responden.

Hasil penelitian menunjukkan daya tarik berpengaruh secara signifikan terhadap perilaku kecanduaan mahasiswa. Besarnya pengaruh daya tarik terhadap perilaku kecanduan mahasiswa adalah $18,9 \%$, hal tersebut menunjukkan bahwa daya tarik didalam aplikasi TikTok baik itu musik, efek kamera, video, dan aktris berpengaruh besar terhadap perilaku kecanduan responden dan pada variabel ini pernyataan kuesioner yang mendapatkan respon sangat baik adalah pada musik dan efek dalam aplikasi TikTok sangat menarik sehingga membuat responden terkesan.

\section{Kesimpulan}

Berdasarkan hasil penelitian dan pembahasan diatas dapat diambil kesimpulan bahwa hasil pengujian hipotesis sub variable pertama, ditemukan bahwa intensitas berpengaruh signifikan terhadap tingkat perilaku kecanduan mahasiswa Prodi Ilmu Komunikasi Angkatan 2018-2019 Universitas Singaperbangsa Karawang. Sub variabel intensitas berpengaruh signifikan terhadap perilaku kecanduan mahasiswa karena nilai signifikansi tersebut lebih kecil dari taraf 5\% yaitu 0,000 < 0,05 dan juga Ttabel 4,603 > 1,99 dan ini bisa dilihat dari besarnya angka persentase koefisien determinasi parsial pada variabel ini yaitu 25,8\%. Dengan demikian sub variabel intensitas penggunaan aplikasi TikTok berpengaruh signifikan terhadap perilaku kecanduan mahasiswa prodi Ilmu Komunikasi. Berdasarkan hasil penelitian maka dapat dilihat bahwa intensitas penggunaan aplikasi TikTok adalah semakin baik intensitas penggunaan aplikasi TikTok, tentu akan semakin meningkatkan perilaku kecanduan. Berdasarkan hasil pengujian hipotesis sub variabel kedua, ditemukan bahwa isi konten tidak berpengaruh signifikan terhadap tingkat perilaku kecanduan. Sub variabel isi konten tidak berpengaruh signifikan terhadap perilaku kecanduan mahasiswa karena nilai signifikansi tersebut lebih besar dari taraf 5\% yaitu 0,375 < 0,05 dan juga Ttabel-0,894 < 1,99 dan ini biasa dilihat dari kecilnya angka persentase koefisien determinasi parsial pada variabel ini, yaitu 1,3\%, dengan demikian sub variabel isi konten berpengaruh signifikan terhadap perilaku kecanduan mahasiswa. Semakin baik isi konten aplikasi TikTok, tentu akan semakin menurunkan perilaku kecanduan. Berdasarkan hasil pengujian hipotesis sub variabel ketiga, ditemukan bahwa daya tarik berpengaruh signifikan terhadap tingkat perilaku kecanduan. Sub variabel daya tarik berpengaruh signifikan terhadap perilaku kecanduan mahasiswa, karena nilai signifikansi tersebut lebih kecil dari taraf 5\% yaitu $0,000<0,05$ dan juga Ttabel 3,770>1,99 dan ini bias dilihat dari besarnya angka persentase koefisien determinasi parsial pada variabel ini, yaitu $18,9 \%$, dengan demikian sub variabel daya tarik berpengaruh signifikan terhadap perilaku kecanduan mahasiswa. Semakin baik daya tarik tentu akan semakin meningkatkan perilaku kecanduan. Berdasarkan uji yang telah dilakukan, peneliti mendapatkan kesimpulan bahwa ketika setiap variabel intensitas, isi konten, dan daya tarik disatukan maka ketiga variabel memiliki pengaruh yang signifikan terhadap perilaku kecanduan mahasiswa. Besarnya pengaruh ketiga variabel terhadap 
perilaku kecanduan yaitu $\mathrm{F}$ hitung 28,8880 > 2,75 F tabel sehingga disimpulkan bahwa Ha diterima yang berarti terdapat pengaruh intensitas (X1), isi konten (X2), daya tarik (X3) secara simultan terhadap perilaku kacanduan (Y). Fakta tersebut menunjukkan variabel-variabel tersebut merupakan aspek yang sangat dominan dalam memengaruhi penggunaan aplikasi TikTok terhadap perilaku kecanduan mahasiswa. Hal tersebut sesuai dengan aspek-aspek kecanduan yang telah dikemukakan oleh Young yang berpendapat bahwa pecandu internet akan menghabiskan waktu untuk online dengan menggunakan aplikasi komunikasi dan tidak dapat mengontrol penggunaannya saat online. Ningtyas juga mengungkapkan pecandu internet kebanyakan disebabkan oleh kepuasan yang mereka temukan di internet dan tak ditemukan didunia nyata. Internet telah membuat remaja kecanduan karena menawarkan berbagai fasilitas informasi, mainan dan hiburan yang membuat para remaja tak dapat lepas dari efek kecanduan tersebut. Hal ini juga berkaitan dengan teori determinasi teknologi dimana teknologi membentuk individu dala berpikir, berperilaku di masyarakat dan teknologi mengarahkan manusia untuk bergerak dari satu abad menuju abad teknologi selanjutnya. Penggunaan teknologi yang berubah seiring waktu memaksa manusia atau penggunanya untuk ikut berubah mengikuti cara dari bagaimana teknologi itu berkerja, sehingga teknologi yang tecipta akan selalu menciptakan kebiasaan-kebiasaan baru bagi penggunanya. 


\section{BIBLIOGRAFI}

Agustriana, Rizky. (2019). Pengaruh Penggunaan Media Elektronik Dan Pola Asuh Orang Tua Terhadap Karakter Anak. Online Thesis, Teknik Sipil. Tasikamalaya: Universitas Siliwangi. Google Scholar

Atikah, Salsabilla. (2018). Hubungan Kebutuhan Relatedness Dengan Kecanduan Media Sosial Pada Remaja. Tesis, Fakultas Psikologi. Riau: Univeristas Islam Negeri Sultan Syarif Kasim. Google Scholar

Bungin, Burhan. (2009). Sosiologi Komunikasi. Jakarta: Kencana Prenada Media Group. Google Scholar

CNN. (2019). Kalahkan Instagram, TikTok Diunduh 1,5 Milyar Pengguna. CNN Indonesia. Retrieved From Https://Www.Cnnindonesia.Com/Teknologi/20191119104916-185 449598/Kalahkan-Instagram-TikTok-Diunduh-15-Miliar-Pengguna. Google Scholar

Damar, A. M. (2019). Jumlah Pengguna Instagram Dan Facebook Indonesia Terbesar Ke4 Di Dunia. Retrieved From Liputan6.Com Website: Https:/Www.Liputan6.Com/Tekno/Read/3998624/Jumlah-Pengguna-InstagramDan-Facebook-Indonesia-Terbesar-Ke-4-Di-Dunia. Google Scholar

Ferdiansyah, M. (2020). Jumlah Unduhan TikTok Kalahkan Facebook Dan Instagram. Retrieved From Oketechno Website: Https://Techno.Okezone.Com/Read/2020/01/16/207/2153835/Jumlah-UnduhanTikTok-Kalahkan-Facebook-. Google Scholar

Ghozali, Imam. (2017). Pengaruh Motivasi Kerja, Kepuasan Kerja Dan Kemampuan Kerja Terhadap Kinerja Pegawai Pada Kantor Kementerian Agama Kabupaten Banjar. Jurnal Ilmiah Ekonomi Bisnis, 3(1), 130-137. Google Scholar

Hayati, Nurul. (2020). Bersaing Dengan Instgram Dan Youtube, Aplikasi TikTok Asal China Tak Hanya Video Receh. Retrieved From Serambinews.Com Website: Https://Aceh.Tribunnews.Com/2020/01/27/Bersaing-Dengan-Instagram-DanYoutube-Aplikasi-TikTok-Asal-China-Tak-Hanya-Video-Receh. Google Scholar

Hurlock, Kathryn, \& Oldfield, Paul. (2015). Crusading And Pilgrimage In The Norman World. Manchester: Boydell \& Brewer. Google Scholar

Janie, Dyah Nirmala Arum. (2012). Statistik Deskriptif \& Regresi Linier Berganda Dengan SPSS. Edited by Ardiani Ika. Semarang: Semarang University Press. Google Scholar

Kaplan, Andreas M., \& Haenlein, Michael. (2012). Social Media: Back To The Roots 
And Back To The Future. Journal Of Systems And Information Technology, 14(1), 101-104. Google Scholar

Mawardah, Mutia. (2019). Adiksi Internet Pada Masa Dewasa Awal. Jurnal Ilmiah Psyche, 13(2), 108-119. Google Scholar

Prianbodo, Bagus. (2018). Pengaruh “TikTok” Terhadap Kreativitas Remaja Surabaya. Surabaya: Stikosa-Aws. Google Scholar

Santrock, John W. (2011). Masa Perkembangan Anak. Jakarta: Salemba Humanika Google Scholar

Sugiyono. (2017). Metode Penelitian. Bandung: Alpabeta. Google Scholar

Surahman, Sigit. (2016). Determinisme Teknologi Komunikasi Dan Globalisasi Media Terhadap Seni Budaya Indonesia. Rekam: Jurnal Fotografi, Televisi, Animasi, 12(1), 31-42. Google Scholar

Tristan, Michael, Sadono, Teguh Priyo, \& Marta, Rustono Farady. (2019). Disintermediasi Industri Musik Melalui Konstruksi Pengguna Akhir Most Viral Project. Ettisal: Journal Of Communication, 4(1), 33-42. Google Scholar

Tyas, Dyah Listianing, Budiyanto, A. Djoko, \& Santoso, Alb Joko. (2015). Pengaruh Kekuatan Media Sosial Dalam Pengembangan Kesenjangan Digital. Scientific Journal Of Informatics, 2(2), 147-154. Google Scholar

\section{Copyright holder:}

Mela Rahmayani, Muhamad Ramdhani, Fardiah Oktariani Lubis (2021)

First publication right:

Syntax Literate: Jurnal Ilmiah Indonesia

This article is licensed under:

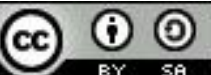

